\title{
Anterior Urethral Valve and Anterior Urethral Diverticulum with an Intradiverticular Stone: A Case Report and a Literature Review
}

\section{Divertikül İçi Taş ile Birlikte Anterior Üretral Valv ve Anterior Üretral Divertikül: Olgu Sunumu ve Literatür Gözden Geçirmesi}

\author{
(D) Serhat Çetin, (D) Murat Yavuz Koparal, (D) Ender Cem Bulut, (D Serhat Gürocak, (D) Özgür Tan \\ Gazi University Faculty of Medicine, Department of Urology, Ankara, Turkiye
}

\begin{abstract}
Anterior urethral valve (AUV) is a rare but well-defined congenital anomaly. AUV can be isolated or occur in association with anterior urethral diverticulum (AUD). Here, we present the first pediatric case report of AUV and AUD which is complicated with an intradiverticular stone. We also review the literature involving AUV with AUD cases.

Keywords: Anterior urethral valve, Anterior urethral diverticulum, Intradiverticular stone

Öz

Anterior üretral valv (AÜV), az görülen fakat iyi tanımlanmış bir konjenital anomalidir. AÜV, izole veya anterior üretral divertikül (AÜD) ile birlikte görülebilmektedir. Biz bu yazıda divertikül içi taş ile komplike olmuş ilk pediatrik AÜV ve AÜD olgusunu raporladık. Ayrıca literatürdeki AÜD ile birliktelik gösteren AüV olgularını da gözden geçirdik.
\end{abstract}

Anahtar Kelimeler: Anterior üretral valv, Anterior üretral divertikül, İntradivetiküler taş

\section{Introduction}

Anterior urethral valve (AUV) is a rare but well-defined congenital anomaly. AUV is a crescent-shaped fold that arises from the base of the urethra. AUV narrows the urethral lumen and may result in obstruction and serious effects on the proximal urinary system (1). AUV frequency is 15 to 30 times lower than posterior urethral valve frequency (2). A small number of AUV cases, both separately and in association with anterior urethral diverticulum (AUD), have been described. We present the first pediatric case report of AUV and AUD which was complicated with intradiverticular stone. We also review the literature involving AUV with AUD cases.

\section{Case Presentation}

A 14-year-old male patient was admitted to our clinic with dysuria, pollakiuria and pain on the tip of the penis during voiding. The patient also had nocturnal and diurnal urinary incontinence. Macroscopic haematuria had been seen only once, two years earlier. Bilateral grade 2 hydroureteronephrosis, 700 cc bladder capacity and 300 cc postvoiding residual (PVR) urine volume were observed on abdominopelvic ultrasonography. Laboratory testing revealed a serum creatinine level of 0.64 $\mathrm{mg} / \mathrm{dL}$ and blood urea nitrogen level of $11.8 \mathrm{mg} / \mathrm{dL}$. Recurrent bacterial growth was found in the urine cultures. Uroflowmetry showed a maximal flow rate $\left(0_{\max }\right)$ of $5.1 \mathrm{~mL} / \mathrm{s}$, average flow rate $\left(\mathrm{O}_{\text {ave }}\right)$ of $1.6 \mathrm{~mL} / \mathrm{s}$, voiding volume of $200 \mathrm{cc}$, PVR of 380 $\mathrm{Cc}_{1}$ and plateau voiding pattern. Detrusor overactivity was observed on videourodynamic study. Before the voiding phase, fluoroscopy revealed $2 \mathrm{~cm}$ opacity in the penile urethra. On voiding phase, anterior urethral stenosis and poststenotic dilatation were observed. Vesicoureteral reflux (VUR) was not observed (Figure 1). Cystourethroscopy confirmed the presence of the AUV and a stone within the AUD (Figure 2a). The AUV was incised by a cold knife and laser (Figure 2b). Following

Correspondence: Murat Yavuz Koparal MD, Gazi University Faculty of Medicine, Department of Urology, Ankara, Turkiye E-mail: drkoparal@yahoo.com 0RCID-ID: orcid.org/0000-0002-8347-5727

Received: 22.03.2017 Accepted: 01.06.2017

Cite this article as: Çetin S, Koparal MY, Bulut EC, Gürocak S, Tan Ö. Anterior Urethral Valve and Anterior Urethral Diverticulum with an Intradiverticular Stone: A Case Report and a Literature Review. J Urol Surg 2018;5(2):109-111.

${ }^{\circ}$ Copyright 2018 by the Association of Urological Surgery / Journal of Urological Surgery published by Galenos Publishing House. 
open surgery for intradiverticular stone extraction and urethral diverticulum excision, reduction urethroplasty was performed. On the postoperative first month, uroflowmetry showed a $\mathrm{O}_{\max }$ of $14.4 \mathrm{~mL} / \mathrm{s}, \mathrm{Q}_{\text {ave }}$ of $4.8 \mathrm{~mL} / \mathrm{s}$, voiding volume of $389 \mathrm{cc}$, and PVR of 52 cc as well as improved voiding pattern. The patient signed informed consent and anonymity has been preserved.

\section{Discussion}

AUV is a rare congenital anomaly that causes lower urinary tract obstruction. AUVs may be located at the distal segment of the membranous urethra. AUVs are most frequently observed in the bulbous urethra segment (40\%) and are seen with similar rates in the penile $(30 \%)$ and penoscrotal regions (30\%). There are few cases described in the fossa navicularis (3). The clinical presentation of AUV is highly variable depending on the age of the patient and the degree of the obstruction. AUV is difficult to diagnose unless the practitioner suspects the condition. It is possible to miss the diagnosis of AUV until adulthood. Common complaints include difficulty in voiding, pollakiuria, urinary incontinence, low urine flow, and recurrent urinary tract infections (4). In the neonatal period and in infancy, AUVs may cause severe obstruction resulting in megacystis, bladder rupture, bilateral hydroureteronephrosis, urinary ascites, and azotaemia (5). VUR is detected in one-third of AUV patients, and renal scarring is observed in half of AUV patients with VUR (6).

AUV can be isolated or may occur in association with AUD. Several theories have been described for the aetiology of AUV and AUD. Some authors suggest that AUV is an incomplete form of urethral duplication, while others suggest that both AUV and AUD are the result of ruptured cystic dilatation of Cowper's gland or other periurethral gland ducts (7). Similarly, it is unclear whether AUV and AUD coexist embryologically or are part of

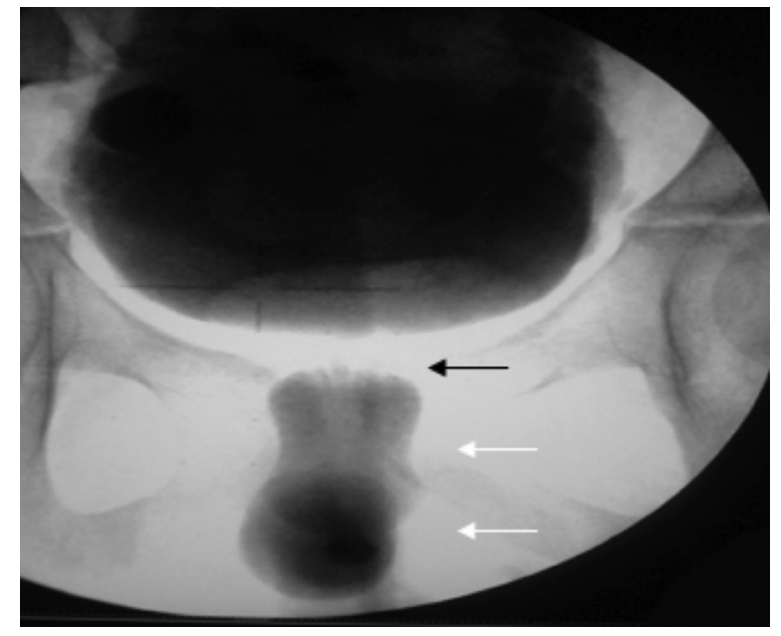

Figure 1. Anterior urethral stenosis (black arrow) and poststenotic dilatation of urethra (white arrows) on voiding phase of voiding cystourethrogram. Vesicoureteral reflux was not observed a continuum. The rarity of these lesions and the difficulties in diagnosing them make it challenging to establish a definite aetiology. Urinary tract infection, fistulas and stone formation in the diverticulum are the most common complications associated with urethral diverticulum (8). As a result of urinary stasis and infection in the diverticulum, a stone may form therein or a renal stone may get trapped in the diverticulum after descending into the bladder (9). In the literature, only one adult case of AUV and AUD, which was complicated with intradiverticular stone, has been reported (10). Our patient is the first pediatric case in the literature. Children with low flow rate and recurrent urinary tract infections should be evaluated carefully. AUV or AUD should be kept in mind during the differential diagnosis of obstructive pathologies. Voiding cystourethrogram (VCUG) is the gold standard imaging method for detection of urethral anomalies (1). For AUV diagnosis, it is necessary to view and evaluate the moment of voiding. In VCUG, dilated or extended posterior urethra, dilated anterior
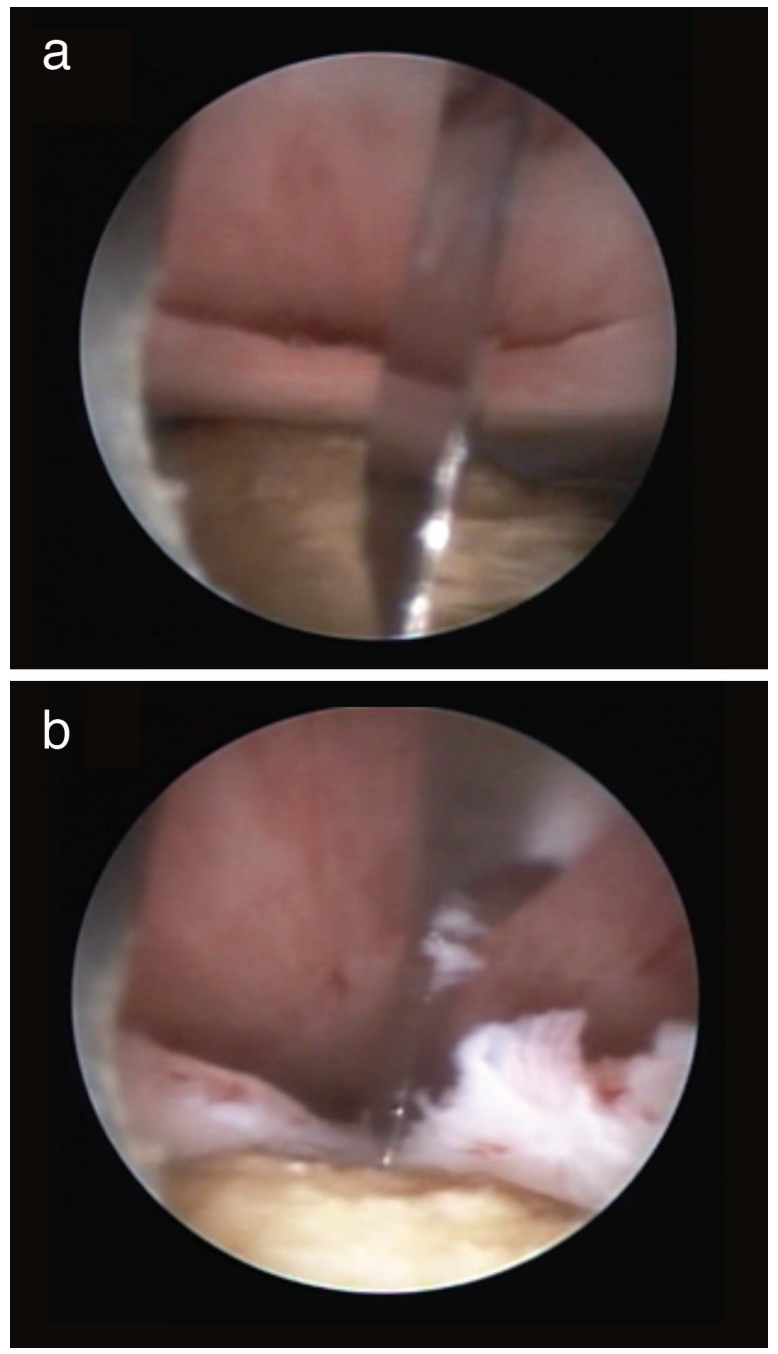

Figure 2. Cystourethroscopic view of the anterior urethral valve and a stone within the anterior urethral diverticulum, (a) anterior urethral valve incision by cold knife (b) 
urethra, thickened and trabecular bladder, VUR, hypertrophic bladder neck, and urethral diverticulum can all be observed. The presence of retrograde fluid flow on the cystourethroscopy complicates the diagnosis by closing the crescent-shaped valves in isolated AUVs. When a patient is admitted with diagnosed or suspected AUV, the first procedure should be the placement of a permanent urethral catheter to allow urine drainage and reduce the risk of urosepsis and renal injury. The definitive treatment for AUV is surgery. Laser, electrocautery and hot or cold knife valve transurethral ablation are highly effective methods to treat AUV. In patients with very low birth weight, in whom endoscopic instrumentation is difficult, a temporary cutaneous vesicostomy may be required. AUD cases can be treated in a single surgical session that includes diverticulectomy and urethroplasty. AUD can also be treated with a two-session procedure. The urethrostomy can be opened from the proximal end of the valve before diverticulectomy and urethroplasty session. Urethrostomy preserves bladder functions better rather than vesicostomy (6). In our case, the AUV was first ablated with laser and cold knife. The diverticulum was excised, the stone was extracted and urethroplasty was performed. In conclusion, AUV with AUD is a rare cause of lower urinary tract obstruction and renal failure. All patients with low urine flow and recurrent urinary tract infections should carefully be evaluated, and AUV and AUD should be kept in mind during the differential diagnosis.

\section{Ethics}

Informed Consent: The patient signed informed consent and anonymity has been preserved.

Peer-review: Externally peer-reviewed.

\section{Authorship Contributions}

Surgical and Medical Practices: S.G., Ö.T., Concept: S.G., Ö.T., Design: S.G., Ö.T., Data Collection or Processing: S.Ç., M.Y.K., E.C.B., Analysis or Interpretation: S.Ç., M.Y.K., E.C.B., Literature Search: S.Ç., E.C.B.,M.Y.K., Writing: S.Ç., M.Y.K.

Conflict of Interest: No conflict of interest was declared by the authors.

Financial Disclosure: The authors declared that this study received no financial support.

\section{References}

1. Jana M, Gupta AK, Prasad KR, Goel S, Tambade VD, Sinha U. Pictorial essay: Congenital anomalies of male urethra in children. Indian J Radiol Imaging 2011;21:38-45.

2. Jehannin B. [Congenital obstructive valves and diverticula of the anterior urethra]. Chir Pediatr 1990;31:173-180.

3. Scherz HC, Kaplan GW, Packer MG. Anterior urethral valves in the fossa navicularis in children. J Urol 1987;138:1211-1213.

4. Zia-ul-Miraj M. Anterior urethral valves: a rare cause of infravesical obstruction in children. J Pediatr Surg 2000;35:556-558.

5. Merrot T, Chaumoître K, Shojai R, D'Ercole C, Alessandrini P. Fetal bladder rupture due to anteriorurethral valves. Urology 2003;61:1259.

6. Van Savage JG, Khoury AE, McLorie GA, Bägli DJ. An algorithm for the management of anterior urethral valves. J Urol 1997;158:1030-1032.

7. McLellan DL, Gaston MV, Diamond DA, Lebowitz RL, Mandell J, Atala A, Bauer SB. Anterior urethral valves and diverticula in children: a result of ruptured Cowper's duct cyst? BJU Int 2004;94:375-378.

8. Popoola AA, Oyinloye OI, Aremu IB. Acquired male urethral diverticulum: case reports. Niger Postgrad Med J 2009;16:224-226.

9. Karanth KS, Yeluri SV, Desai RM, Shah SC. Congenital anterior urethral diverticulum with stone: a unique presentation. Urology 2003;61:837.

10. Thakur N, Sabale VP, Mane D, Mullay A. Male urethral diverticulum uncommon entity: Our experience. Urol Ann 2016;8:478-482. 